\title{
Application of problem based learning model to learning outcomes of student in light matter in the class VIII SMP Negeri 1 Ledo kabupaten Bengkayang
}

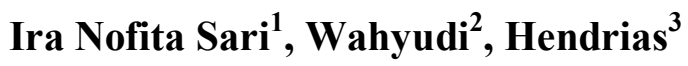 \\ 1,2,3 Physic Education Study Program, IKIP-PGRI Pontianak \\ Ampera Street Number 88 Pontianak \\ 1Email: iranofitasari87@gmail.com
}

Received 15 October 2016, Revised 24 November 2016, Accepted 3 January 2017

\begin{abstract}
This study aims to determine: (1) student learning outcomes after application of the model Problem Based Learning on the material light in class VIII SMP Negeri 1 Ledo Bengkayang, (2) student learning outcomes after application of conventional learning models on the material light in class VIII SMP Negeri 1 Ledo Bengkayang, and (3) a comparison between student learning outcomes after application of Problem Based learning and conventional learning models in light of the material in class VIII SMP Negeri 1 Ledo Bengkayang. This study design is Nonequivalent Groups Post-Test Only Design. The study population was all students of class VIII SMP Negeri 1 Ledo consisting of four classes, namely class VIII A, VIII B, $\mathrm{C}$ VIII and VIII D. The research sample was determined by random cluster sampling technique and obtained a class VIII A as the experimental class and class VIII $\mathrm{C}$ as the control class. The data collection technique used is the technique of measurement, with the data collection tool is test description. The hypothesis was tested using the $t$ test of the parties. Based on the analysis concluded that: (1) the average student learning outcomes after application of the model Problem Based Learning on light material in class VIII SMP Negeri 1 Ledo Bengkayang is 73.24, (2) student learning outcomes after application of conventional learning model in the light of the material in class VIII SMP Negeri 1 Ledo Bengkayang is 69.82, and (3) student learning outcomes after application of the model Problem Based learning is better than the student learning outcomes after application of conventional learning models in light of the material in class VIII SMP Negeri 1 Ledo Bengkayang.
\end{abstract}

Keyword: application; learning outcomes; Problem Based Learning model; light.

\section{Introduction}

Natural Sciences (IPA) with regard to how to find out about natural phenomena systematically, so that science is not just a collection of knowledge in the form of facts, concepts, or principles alone but a series of activities that are investigating of IPA.

Physics lesson is one important part of science that students are learning. Physics study natural phenomena such as motion, heat, light, sound, electricity, and 
magnet.Semua this phenomenon is a form of "energy" Hence, it can be said that physics is the science which mainly studied the relationship between matter and energy (Kanginan 2006).

Lessons can be said to be optimal is learning where the teacher does not just explain the course but students should be more actively to seek out and build their own knowledge as well as the teacher's role as facilitator and motivator, it is intended to make students more independent/skilled and active during the learning takes place. Learning class will be very effective if teachers do it with understanding the role, fungsidan usefulness of the subjects taught.

Physics here for some students still regarded as a difficult subject. Is said to be difficult because of the physics associated with formulas that require students to understand the concepts and skills to carry out mathematical calculations. Based on interviews with teachers in SMP Negeri 1 Ledo, material physics elusive students is one of light materials. Light material considered difficult by students because a lot of drawing, memorize and lots of abstract mathematical calculation and thus are hard to understand. Based on observations in the class known that active students in the learning process is also low and learning is still centered on the teacher. When the teacher explains the material, the students only listen, take notes, and when given the opportunity to ask the students no one to ask. Students are less interested in learning because students are less actively involved. This resulted in less students participate in learning activities that tend to make students get bored and less time concentrating on learning. Various of the above resulted in less than optimal student learning outcomes revealed by the daily tests on the material light and have not reached the minimum completeness criteria set the school is 70 . The average value of daily test students light on the matter last three years can be seen in Table 1.

Based on Table 1 are known the low average value of daily test students on the material light. It shows that appropriate learning models needed to make the learning process, especially science subjects (physics) can achieve maximum results. Adi, et al (2014) concluded that the use of appropriate learning models should be able to improve results student learning.

Table 1. The Average Value of Daily Test on Light Material in The Class VIII SMP Negeri 1 Ledo

\begin{tabular}{cccc}
\hline & \multicolumn{3}{c}{ Average Value } \\
\cline { 2 - 4 } Class & In & In & In \\
& 2013 & 2014 & 2015 \\
\hline VIII A & 67,11 & 69,33 & 69,29 \\
VIII B & 67,36 & 68,17 & 68,71 \\
VIII C & 66,21 & 68,97 & 69,18 \\
VIII D & 66,71 & 68,52 & 69,09 \\
\hline
\end{tabular}

One of model that can be appropriate learning is Problem Based Learning. Problem Based Learning as a model gives freedom of thought and skill in solving problems to the students in the learning process by using a real problem. Teachers in this model 
serve as presenters problem, the questioner, holding a dialogue, and help find the problem.

Problem Based Learning model application in light of the material due to the light material students learn about the reflectance of light is an abstract thing, so students are difficult to understand the concepts and equations exist. Problem Based Learning model will help the student to learn the material so that the light can be formed abstract concepts in practice. Through the model of Problem Based Learning students will be directed to resolve the issues presented at the beginning of learning the stages of learning where the teacher gives a problem related to the material to be conveyed, organizing students to learn, lead students to address issues being discussed so that the concept was abstract can be formed with the real concept, asked the students to express their opinions, and provide feedback and give conclusions on troubleshooting.

According to Sanjaya (2006), the learning model Problem Based Learning can make students more active, can improve students' ability to solve problems in everyday life, creating new ideas, can increase intimacy and cooperation, and make education in schools to be more relevant with life. The most important aspect of Problem Based Learning is that learning begins with problems and these problems will determine the direction of learning in groups.

The concept of problem solving on the model of Problem Based Learning is done by a group discussion. Problem Based Learning method more emphasis on exchanging views and sharing experiences in problem solving (Wulandari, 2013). Through the model of Problem Based Learning students will be motivated and interested to explor the knowledge and desire to learn something new in order to solve the problems associated with the real world. Not only the positive attitude, which is important to mention that the implementation of the learning model Problem Based Learning course can improve student learning outcomes and student learning activities (Kharida, 2009). In addition, according to Gallagher (2013) Problem Based Learning can create learning context that encourages more students to reveal academic potential.

Based on the above, this study was conducted to clarify the objective for the learning outcomes of students after learning to use the given model of Problem Based Learning in learning physics, especially in light of the material.

\section{Methodology}

This research was conducted using the experimental method to form Quasi Experimental Design. This research was conducted using the experimental method to form Quasi Experimental Design. The research method is experimental research methods used to find a particular influence (Sugiyono, 2013). Treatment class is divided into two groups: the experimental group and the control group. The experimental group used the model of Problem Based Learning and the control group using model konvensional. The research design used is Nonequivalent Groups Post-Test Only Design.

The population in this study were all students of class VIII SMP Negeri 1 Ledo consisting of four classes, namely class VIII A, VIII B, C VIII and VIII D. The sampling technique used to determine the experimental class and control class is cluster 
random sampling to draw a sample of a homogeneous population based on test Barltllet. The results of the draw, obtained VIII $\mathrm{A}$ as the experimental class and VIII $\mathrm{C}$ as the control class.

Data collection techniques used in this research is a measurement technique. Measurements referred to in the study of awarding achievement test students taught by Problem Based Learning models and conventional models in light material. Data collection tool used in this study is in the form of student achievement test berbantuk essay test that has been qualified valid and reliable (Sudjana, 2005).

Based on trial results, it can be seen that the question is valid with a high degree of validity. Based on the calculation formula alpha reliability coefficient of 0.7970 which means the values obtained reliability coefficient test questions are reliable and have high reliability.

\section{Results and Discussion}

Data obtained from this study is data posttest of the experimental class that implemented the model of Problem Based Learning and grade control applied to conventional learning models as a representation of student learning outcomes in light of the material.

Based on the recapitulation of learning outcomes that applied the model of Problem Based Learning and conventional learning models in mind that the average score of posttest in the experimental class that implemented the model of Problem Based Learning is 73.24 with standar deviation 6.937 and grade control applied to conventional learning models for 69.82 with standar deviation 6.279. This shows that the learning outcomes of students who applied the model of Problem Based Learning is better than on the learning outcomes of students who applied conventional learning models. Differences in learning outcomes of students in the experimental class and control class can be seen in Figure 1.

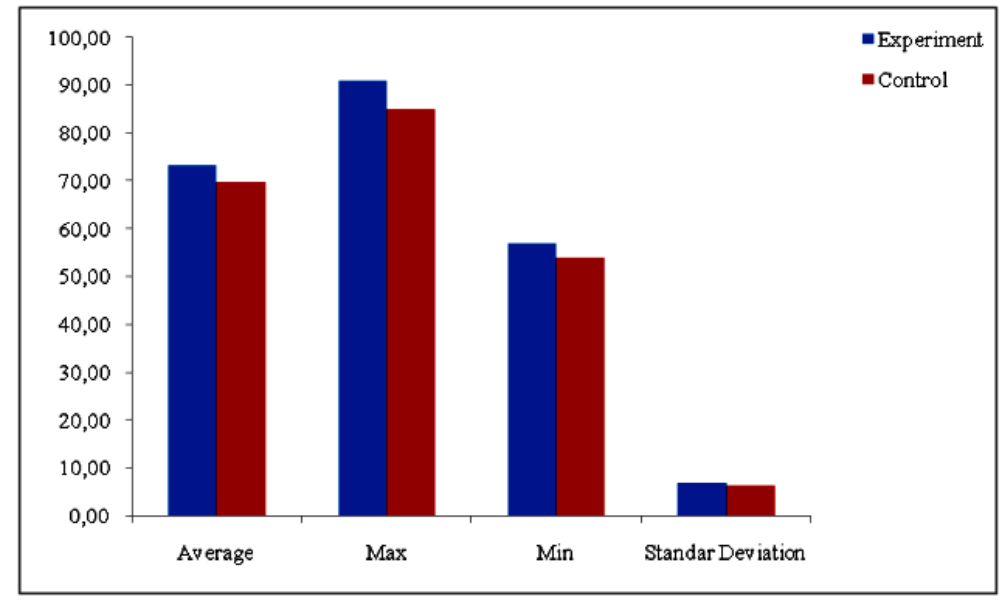

Figure 1. Histogram of Posttest Data

To determine differences in learning outcomes of the experimental class and control class performed statistical tests, but previously conducted a preliminary test first, the test for normality and homogeneity test. 
Normality test results from the test results of students' experimental class and control class by using Chi Square $\left(\chi^{2}\right)$, the price obtained test statistic significant level of $5 \%$ in each sample are shown in Table 2.

Table 2. Normality Test Result

\begin{tabular}{cccc}
\hline Class & $\chi_{\text {count }}^{2}$ & $\chi_{\text {table }}^{2}$ & Conclusion \\
\hline Experiment & $-5,053$ & 7,815 & Normal \\
Control & $-67,544$ & 7,815 & Normal \\
\hline
\end{tabular}

Based on Table 1 it is known that $\chi^{2}$ count $<\chi$ table in the experimental class and control class, it can be concluded that both classes of samples derived from normal distributed population. The results of the test $F$ known that $F_{\text {count }}(1.221)<F_{\text {table }}(1.804)$, so it can be said that both classes are homogeneous.

Based on the analysis prerequisite test is shown that both normal and homogeneous distribution of data, then the hypothesis testing using statistical parametric independent samples $t$ test (one party). Based on calculation results obtained $t_{\text {count }}(2.1024)>t_{\text {table }}$ (1.9980), then in these circumstances $\mathrm{H}_{0}$ rejected and $\mathrm{H}_{\mathrm{a}}$ accepted. Decisions test student learning outcomes are taught using a model Problem Based Learning is better than on learning outcomes for students taught by using conventional learning models in light of the material in class VIII SMP Negeri 1 Ledo Bengkayang.

Differences in student learning outcomes between the experimental class and control class because of the treatment given to the teaching and learning process is a model Problem Based Learning is a learning model that can help students to develop their knowledge to solve problems, and helps students gain important concepts and knowledge in accordance with the material being studied. The experimental class learning process using worksheets, students learn in groups to solve problems found in student woorksheet. Various positive attitude and motivation are visible and grow in learning after application of this model. A positive attitude (scientific attitude) and motivation can be strong capital in the study and make student achievement be better than before (Wahyudi, 2015). Steps to Problem Based Learning model learning greatly assist students in completing the worksheets that make students become active when the process of learning and problem solving processes.

Through stages or phases contained in the model of Problem Based Learning students greatly helped in addressing the problems contained in student woorksheet. The first phase of the orientation of students on the issue. At the first meeting, the orientation is giving researchers a problem related to the reflectance of light material such as questions related to the subject of "Why are you able to see your reflection in the mirror?". The question was responded by the students to answer according to his opinion. At the second meeting of the problem in the form of the question "Why do we tend to use a flat mirror than concave mirror or a convex mirror to reflect? Is the shadow formed on the third mirror different?". The second phase which is organizing students to learn, this phase lead students to learn in groups, and engage students workmanship student woorksheet. 
At the first meeting of the researchers divided the students into six groups and directs students to sit in accordance with each group, and then distribute worksheets to each group and explain the way the process. At the second meeting, researchers directed students to sit back suitable group that has been shared at the first meeting, then distribute and explain again how student woorksheet workmanship. There are some groups who do not understand the way it student woorksheet pada first meeting and the second meeting, then the researcher explains how the process back to the group who do not understand it. The third phase was to assist the investigation of individual and group. Researchers assist students in discussing the issues contained in student woorksheet at the first meeting and the second meeting student woorksheet by giving guidance or direction through questions that are appropriate to the issues discussed. In this phase, students will construct their own knowledge to solve problems that in this case the teacher provide facilities to assist this process. According Hapsari (2011) that the students build their own knowledge will be able to improve learning outcomes and activities.

The fourth phase, which was to develop and present hasi work, giving students the chance to express their opinions in solving the problems that are being discussed, in this phase the researchers asked one group to present the results of their discussion to the class, and then provide the opportunity for other groups to provide feedback on results discussion of the group, so that students can exchange opinions between groups in solving the problems they discussed. The fifth phase of analyzing and evaluating the problem-solving process, this phase provides an opportunity for students to jointly evaluate the right answer or the wrong answer from student woorksheet they do so they can conclude the material being studied. In addition, students can also interact with friends in a group to exchange ideas that can improve keakrabaan and cooperation within a group.

The learning process at a second meeting can be said there is an increasing involvement of the student, for the second meeting of the students have started to understand the learning model used. If the first meeting is still a shy student who asked his friend when the discussion, at the second meeting no more students were shy to ask his friend. When seen from the results of the discussion, the value obtained at the first meeting of each group is greater than the value obtained in the second meeting that, for the highest score at the first meeting is 94.00 and the second meeting is 67.81. This is because at the first meeting of worksheets that students did nothing about the matter while the second meeting student woorksheet done most of the problems require siswauntuk done counting, this shows that the students' skills in numeracy are still lacking. Lack of students' skills in numeracy is also evident from the results of the posttest not reach the minimum completeness criteria in indicator math that can be seen in Figure 2.

Unlike the experimental class taught by using the model of Problem Based Learning, the control class of students taught using conventional learning models using the lecture method. The steps of learning is the teacher gives apersepsi continued by explaining the material and provide examples relating to the material glow. The learning process 
without the worksheets, the teacher explains the material and students simply record what is described by teachers, so students do not understand the material given by the teacher. When given the opportunity to ask a few students who actively ask while others tend to be quiet and shy to ask questions, no discussion among students resulting in students not able to develop the ability to solve problems in everyday life. There is no difference when learning at the first meeting and the second meeting, the students just taking notes what is described by teachers even do not focus on learning. As an experimental class, the control class students' skills in numeracy are also less, which can be seen in Figure 2.

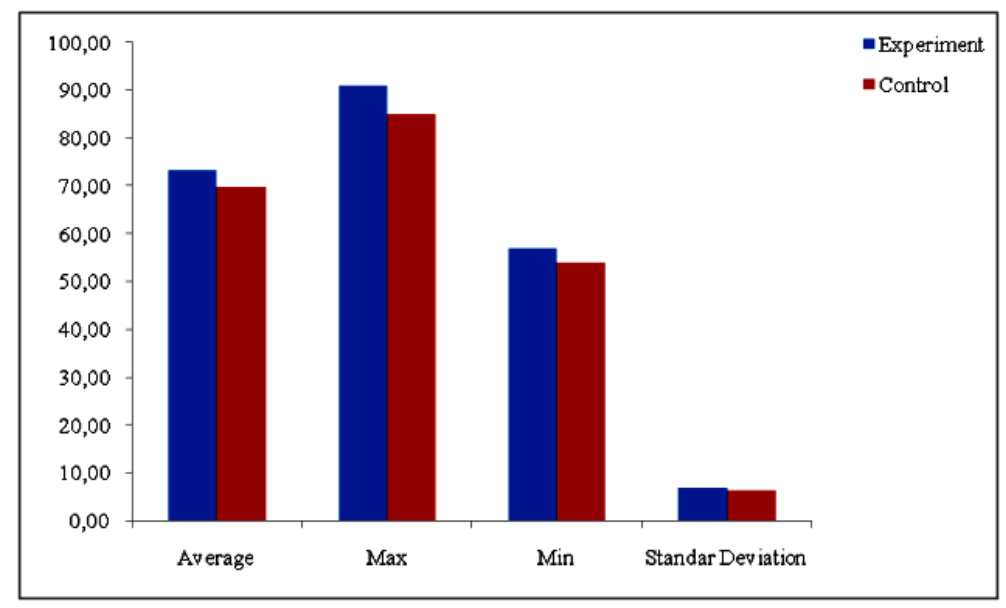

Figure 2. Achievement of Value Every Indicators

The results obtained in this study are consistent with research conducted by Adi, et al (2014), Hamdani et al (2015) and Lisna et al (2015) concluded that the application of the model of Problem Based Learning can improve student learning outcomes. Thus the application of the model of Problem Based Learning potentially influence student learning outcomes in light of the material so that it can be used as an alternative in learning physics, especially light material.

\section{Conclusion}

Based on the results of the processing of the data obtained through experimental studies, in general it can be concluded that the application of the model Problem Based Learning on light material in class VIII SMP Negeri 1 Ledo Bengkayang influence on student learning outcomes. Learning outcomes of students who are taught by the model of Problem Based Learning is better than learning outcomes of students taught by conventional learning models.

\section{References}

Adi, Nugroho Prasetya; Ayu N. M, Ngurah and Nuvitalia, Duwi. (2014). Penerapan Model Pembelajaran Problem Based Learning Pokok Bahasan Kalor untuk Meningkatkan Hasil Belajar Siswa Kelas X SMA N 11 Semarang. Prosiding Mathematics and Sciences Forum 2014. 
Gallagher, Shelag A. and Gallagher, James J. (2013). Using Problem Based Learning to Explore Unseen Academic Potential. IJPBL Interdisciplinary Journal of Problem-Based Learning. 7(1), pp.111-131.

Hapsari, Rr. Tri Sumi. (2011). Penerapan Model Pembelajaran Kontruktivisme untuk Meningkatkan Hasil Belajar IPA. Jurnal Pendiddikan Penabur. 16, pp. 34-45.

Kanginan, Marthen. (2007). IPA Fisika untuk SMP Kelas VIII. Jakarta: Erlangga.

Kharida, L. A.; Rusilowati, A.; and Pratiknyo, K. (2009). Penerapan Model Pembelajaran Berbasis Masalah untuk Peningkatan Hasil Belajar Siswa pada Pokok Bahasan Elastisitas Bahan. Jurnal Pendidikan Fisika Indonesia 5, pp. 8389.

Lisna; Jusuf, Ridwan; Masrifah. (2015). Penerapan Model Pembelajaran Berbasis Masalah untuk Meningkatkan Hasil Belajar Siswa pada Pokok Bahasan Getaran dan Gelombang di SMP Negeri 1 Kota Ternate. dalam Prosiding Seminar Nasional Fisika (E-Journal) SNF 2015 Volume IV.

Sanjaya, Wina. (2010). Strategi Pembelajaran Berorientasi Standar Proses Pendidikan. Jakarta: Kencana.

Sudjana, Nana. (2005). Penialian Hasil Proses Belajar Mengajar.Bandung: PT. Remaja Rosdakarya.

Sugiyono. (2013). Metode Penelitian Pendidikan. Bandung: Alfabeta.

Wahyudi, W. (2015). Analisis Kontribusi Sikap Ilmiah, Motivasi Belajar dan Kemandirian Belajar terhadap Prestasi Belajar Mahasiswa Prodi Pendidikan Fisika STKIP PGRI Pontianak. JEMS Jurnal Edukasi Matematika dan Sains. 1(2), pp. 20-3.

Wulandari, Bekti. (2013). Pengaruh Problem Based Learning terhadap Hasil Belajar Ditinjau dari Motivasi Belajar PLC di SMK. Jurnal Pendidikan Vokasi. 3(2). 